\title{
Metacognitive Knowledge: A Tool For Academic Success
}

\author{
Pallavi Panchu1 ${ }^{*}$, Biju Bahuleyan², Seethalakshmi K ${ }^{3}$, TomThomas ${ }^{4}$ \\ ${ }^{1}$ Associate Professor, 2Professor and HOD, ${ }^{3}$ Postgraduate student, Department of Physiology, \\ ${ }^{4}$ Biostatistician, Department of Biostatistics, \\ Jubilee Mission Medical College and Research Institute, Thrissur, Kerala, India.
}

\begin{abstract}
Introduction: In a dynamic and stressful environment like medical field, where one has to be a lifelong learner, any tool that will simplify and facilitate the learning process and improve the learning outcome is welcome. Awareness of metacognitive knowledge along with its sub components is one such tool.

Method: This cross sectional study was done on all the first year medical students in a college in South India. Metacognitive knowledge questionnaire (testing procedural, declarative and conditional knowledge), a validated tool was administered to all the students. Cumulative academic scores of the full academic year of I MBBS were considered. Data was analysed using ANOVA and Spearson's correlation tests on SPSS version 22.
\end{abstract}

Results: Metacognitive knowledge has a linear relation with academic performance as does its sub components. Metacognitive knowledge and its subcomponents show a statistically significant positive correlation with academic scores.

Conclusion: As educators, designing and inculcation of strategies to improve metacognitive knowledge would

\section{INTRODUCTION}

'To know is to know that you know nothing. That is the meaning of true knowledge.'

Socrates.

Knowledge is an integral part of the education process. Educators worldwide strive to instil the drive for knowledge acquisition in their learners and examinations test the fruits of this labour. The end points of examinations are the scores and low scores find the psycho pedagogical teams helpless in the face of the realization that they lack the tools and expertise to help the students gain knowledge ${ }^{1}$. Routine didactic lectures disseminate knowledge equally among all the students, but, some students outperform the others. This raises the question as to what factors make a student a good learner and satisfactory performer.

A blend of effective reading strategies, learning strategies, selfregulation, self-reflection and self-motivation makes a student an expert learner ${ }^{2}$. Self-reflection or metacognitive awareness of one's own incompetencies or competencies is the path for academic progress. Current research indicates that expert learners and novices differ both qualitatively and quantitatively emphasising the role of metacognitive awareness ${ }^{3-5}$. Contrary to popular belief, it cannot be assumed that students intrinsically empower the students and be the key for their academic success.

Key words: Metacognitive knowledge, Procedural knowledge, Declarative knowledge, Conditional knowledge, Academic success.

\section{*Correspondence to:}

\section{Dr Pallavi Panchu}

Associate Professor

Department of Physiology,

Jubilee Mission Medical College and Research Institute,

Thrissur, Kerala, India.

\section{Article History:}

Received: 12-08-2016, Revised: 16-08-2016, Accepted: 19-08-2016

\begin{tabular}{|l|r|}
\hline \multicolumn{2}{|c|}{ Access this article online } \\
\hline Website: & Quick Response code \\
www.ijmrp.com & \\
\hline DOI: & \\
10.21276/ijmrp.2016.2.5.026 & \\
\hline
\end{tabular}

possess metacognitive abilities ${ }^{6}$. Doctors are lifelong learners and the importance of metacognition in them cannot be over emphasized.

Metacognitive abilities involve metacognitive knowledge, metacognitive regulation and metacognitive experiences. As stated by Flavell, metacognition is the awareness of one's own thinking process ${ }^{7}$. An ideal combination of all these three parameters makes one an expert learner. The psycho-affective aspects like knowing not only what is important but also how, when, where and why to apply the knowledge and actions helps in learning ${ }^{8}$. This led to the emergence of the sub components of metacognition namely declarative knowledge, procedural and conditional knowledge ${ }^{9}$. The general knowledge that the learner acquires about himself and may potentiate the learning process is declarative knowledge. It may be affected by variables such as age, language, aptitude and motivation ${ }^{10}$. A successful student is the one who approaches an academic challenge with confidence and diligence and is able to implement declarative knowledge to practice. Such knowledge is called procedural knowledge ${ }^{11}$. Procedural knowledge if practiced over a period of time becomes automatic. The ability to understand the situation in which a 
particular type of knowledge has to be applied is conditional knowledge. It also means understanding why and when to apply forms of declarative and procedural knowledge ${ }^{11}$. It stands to reason that procedural knowledge and declarative knowledge are thus prerequisites for good conditional knowledge. The usage of these variables affects the outcome of cognitive experiences.

The development of metacognitive knowledge begins in kindergarten and continues to progress over the entire life span as long as the educational processes continue to challenge the learner ${ }^{12-14}$. The dynamism of the medical profession never ceases to challenge a health professional leading to an environment enriched in metacognitive experience. This present study was formulated keeping in mind the importance of metacognitive knowledge and its components and their role in the academic future of a medical student.

\section{MATERIAL AND METHODS}

This cross sectional study was done in Jubilee Mission Medical College and Research Institute, in Kerala on all the first year medical students after obtaining the institutional ethics clearance from August 2015-July 2016. 86 students consented to participate in the study. Clear instructions were given to the students and the metacognitive knowledge questionnaire was administered to them during college hours. It took them about ten minutes to fill the questionnaire. The results so obtained was tabulated and analysed.

Metacognitive knowledge questionnaire: This questionnaire forms a component of the metacognitive awareness inventory questionnaire. It has 17 true or false questions testing the declarative (8 questions), procedural (4) and conditional knowledge (5) domains. For each question that is marked 'true', one mark is given and the total marks tabulated in each category ${ }^{11}$. Three categories, low scorers $(<50 \%)$, average (50$80 \%)$ and high scorers (>80\%) were made for the purpose of analysis depending of the percentage of the scores obtained.

Academic scores: The performance of the students in each of the first year subjects in the Indian medical syllabus namely Anatomy, Physiology and Biochemistry was assessed. The average of the aggregate of the whole year's performance in each subject and overall was calculated. The mean of the overall performance was used for statistical analysis. Single test performance grades or only university exam scores may be influenced by many variables other than knowledge like physical illness and stress. Hence the cumulative performance of the student for the whole academic year was considered.
Statistical analysis: ANOVA, and Spearson's correlation studies were done on the tabulated data using SPSS (statistical package for social sciences) version 22.

\section{RESULTS}

The study included 86 participants of which 49 were girls.

Table 1: Comparison of metacognitive knowledge and academic scores

\begin{tabular}{|c|c|c|c|c|}
\hline $\begin{array}{l}\text { Metacognitive } \\
\text { knowledge }\end{array}$ & $\mathbf{N}$ & $\begin{array}{c}\text { Academic } \\
\text { Mean }\end{array}$ & $\begin{array}{c}\text { Std. } \\
\text { Deviation }\end{array}$ & $P$ value \\
\hline$<50$ & 18 & 62.96 & 8.9 & $0.001^{* * *}$ \\
\hline $50-80$ & 54 & 63.02 & 7.72 & \\
\hline$>80$ & 14 & 65.48 & 9.09 & \\
\hline
\end{tabular}

Table 2: Comparison of declarative knowledge with academic mean (descriptive statistics)

\begin{tabular}{lccc}
\hline $\begin{array}{l}\text { Declarative } \\
\text { knowledge }\end{array}$ & N & Academic Mean & Std. Deviation \\
\hline$<50$ & 19 & 61.6668 & 7.63751 \\
$\mathbf{5 0 - 8 0}$ & 57 & 63.5382 & 8.22071 \\
$>\mathbf{5 0}$ & 10 & 66.0010 & 8.93061 \\
\hline
\end{tabular}

Table 3: Comparison of procedural knowledge with academic mean (descriptive statistics)

\begin{tabular}{lccc}
\hline $\begin{array}{l}\text { Procedural } \\
\text { knowledge }\end{array}$ & $\mathbf{N}$ & Academic Mean & Std. Deviation \\
\hline$<50$ & 35 & 62.9523 & 8.55713 \\
$\mathbf{5 0 - 8 0}$ & 51 & 63.7261 & 7.96994 \\
$>\mathbf{8 0}$ & 0 & 0 & 0 \\
\hline
\end{tabular}

Table 4: Comparison of conditional knowledge with academic mean (descriptive statistics)

\begin{tabular}{lccc}
\hline $\begin{array}{l}\text { Conditional } \\
\text { knowledge }\end{array}$ & N & Academic Mean & Std. Deviation \\
\hline$<50$ & 20 & 62.6670 & 8.80911 \\
$\mathbf{5 0 - 8 0}$ & 51 & 63.1376 & 7.08440 \\
$>\mathbf{5 0}$ & 15 & 65.3333 & 10.77000 \\
\hline
\end{tabular}

Table 5: Correlation of metacognitive knowledge and its sub components with academic success

\begin{tabular}{|c|c|c|c|c|c|c|}
\hline \multicolumn{2}{|c|}{ Spearman Correlations } & \multirow{2}{*}{$\frac{\text { Academic mean }}{1}$} & \multirow{2}{*}{$\frac{\mathrm{I}(4)}{0.015}$} & \multirow{2}{*}{$\frac{\text { II (8) }}{0.181}$} & \multirow{2}{*}{$\begin{array}{l}\text { III (5) } \\
0.072\end{array}$} & \multirow{2}{*}{$\frac{\mathrm{I}-\mathrm{III}}{0.115}$} \\
\hline $\begin{array}{l}\text { Academic } \\
\text { mean }\end{array}$ & Correlation Coefficient & & & & & \\
\hline $\mathrm{l}(4)$ & Correlation Coefficient & & 1 & & $0.345^{* *}$ & $0.592^{2+*}$ \\
\hline$\|(8)$ & Correlation Coefficient & & & 1 & $0.362^{* *}$ & $0.739^{* * *+}$ \\
\hline $\mathrm{III}(5)$ & Correlation Coefficient & & $0.345^{* *}$ & $0.362^{* *}$ & 1 & $0.766^{*+*}$ \\
\hline I-III & Correlation Coefficient & & $0.592^{*+*}$ & $0.739^{* * *}$ & $0.766^{*+*}$ & 1 \\
\hline
\end{tabular}

${ }^{* *}$ Correlation is significant at the 0.01 level (2-tailed). ${ }^{* *}$ Correlation is significant at the 0.001 level (2-tailed).

I-Procedural Knowledge, II- Declarative Knowledge, III- Conditional Knowledge, I-III- Metacognitive Knowledge. 


\section{DISCUSSION}

Awareness of metacognitive knowledge empowers learners by giving them an understanding of how they think. It further helps them reflect on their strengths and weaknesses as learners and guides them toward remedial measures. In this study, we analysed the general metacognitive knowledge, and its subcomponents namely, declarative, procedural and conditional knowledge, of the first year medical students and compared it with their academic scores.

In table 1 metacognitive knowledge scores were divided into three categories: low scorers $(<50 \%)$, average $(50-80 \%)$ and high scorers $(>80 \%)$ and it was found that majority of our participants had average metacognitive knowledge. On analysing the data, a high statistical significance was found between the groups. It was observed that knowledge of metacognition and academic scores share a linear relationship. Researcher like Coutino et al, Narang et al and Young et al reported similar findings ${ }^{15-17}$. The implication of this observation is that students were aware of themselves as learner, the strategies as well as the conditions in which these strategies would be useful16. Only 18 [n=86] of our participants had low levels of metacognition which makes them unaware of their incompetencies as learners.

The role of declarative knowledge in academic performance is analysed in table 2. Declarative knowledge which forms the stepping stone in the process of acquisition of metacognitive knowledge was average in most of our participants. The table also shows the existence of a directly proportional relationship between declarative knowledge and success in examinations. Research which sheds light on subcomponents of metacognitive knowledge still remains at its infancy.

Table 3 shows a comparison between procedural knowledge and academic scores. This brings to light an important observation. 35 of our participants $(n=86)$ have low procedural knowledge, while only 19 had poor declarative knowledge (table2). Also interesting is the fact that none of our participants have high procedural knowledge making the role and focus of us educators very clear. This further emphasises that though our students are aware of their lacunae, they are unable to or unwilling to take corrective steps. It can hence be hypothesised that lack of goal setting and motivation on the part of the learner must contribute to this effect. Conditional knowledge is the knowledge we have about the conditions under which various cognitive strategies can be implemented. It forms and integral part of self-regulated learning. As seen in table 4, comparison of conditional knowledge and academic scores also shows a linear trend with most of our students having average conditional knowledge. The importance of conditional knowledge lies in the fact that it is a conglomeration of procedural and declarative knowledge and hence all the components of metacognitive knowledge are interrelated.

Having established the fact that metacognitive knowledge and its sub components are inter related, we were curious enough to study their correlation which is shown in table 5. Correlation analysis between metacognitive knowledge, its sub components and academic scores show that knowledge positively correlate with all the sub components and to a statistically significant level. The correlations are noted in all the parameters studied while statistical significance is seen between metacognitive knowledge and its sub component. Conditional knowledge had a significantly positive correlation with declarative and procedural knowledge while both procedural and declarative knowledge have significant positive correlation with only conditional knowledge. This reiterates the fact that conditional knowledge can be developed only if the other two are.

\section{CONCLUSION}

The results of the study are promising as it acts as identification tool of students with low metacognitive knowledge. It also helps the teachers' flag students in need of metacognitive awareness training with respect to the different subcomponents. It further helps facilitators develop an enriched environment which provides students with metacognitive experiences and hence empowers them as learners. To make our average students expert learners, we as educators must design support training programs to help them in their endeavour to set effective and realistic goals and motivate them to get there.

\section{ACKNOWLEDGEMENT}

We are grateful for the whole- hearted support of the students who participated in the study.

\section{ETHICS CLEARANCE}

Obtained from institutional ethics clearance committee.

\section{REFERENCES}

1. Frenkel $S$. Metacognitive components in learning to learn approaches. International Journal of Psychology: A Biopsychosocial Approach 2014;14:95-112

2. Lindner R W, Harris B. Self regulated learning: Its assessment and Instructional implications. Educational Research Quarterly 1992; 16(2):29-36

3. Alexander P A, Judy E. The interaction of domain specific and strategic knowledge in academic performance. Review of Educational Research 1988; 58:375-404

4. Bruer J T. The mind's journey from novice to expert. American Educator 1993; 17(2):6-46

5. Parris S G, Lipson M Y, Wixcon K K. Becoming a strategic reader. Contemporary Educational Psychology 1983; 8:293-316.

6. Israel, Susan E (2007). Using metacognitive assessments to create individualized reading instruction. Newark DL: International Reading Association. Ivey G, Fisher D (2006). When thinking skills Trump Reading Skills. Educational Leadership, oct 16-21. Alexandria VA: Association of Supervision and Curriculum (ASCD) 7. Rani R, Govil P. Metacognition and its correlates: A study. IJAESS 2013; 1(1):20-25.

8. Schunk D H. Goal setting and self-evaluation: A social cognitive perspective on self-regulation 1991a. Advances in motivation and achievement; 7: 85-113.

9. Brianna M Scott, Mathew G Levy. Metacognition: Examining the components of a fuzzy concept. Educational Research 2013; 2(2):120-131.

10. Yanyan Z. Investigating the Role of Metacognitive Knowledge in English Writing.HKBU Papers in Applied Language Studies 2010;14:25-46.

11. Ertmer PA, Newby TJ. The expert learner: Strategic, selfregulated, and reflective. Instructional Science 1996; 24:1-24.

12. Schneider W, Lockl K. The Development Of Metacognitive Knowledge In Children And Adolescents. In: T. Perfect, B.Schwartz (Eds). Applied Metacognition, 224-257. 
13. Veenman $M \vee J$, Van HW, BHAM \& Affl Erbach $P$. Metacognition And Learning: Conceptual And Methodological Considerations. Metacognition and Learning; 1:3-14.

14. Alexander JM, Schwanenflugel PJ. Development Of Metacognitive Concepts About Thinking In Gifted And Non-Gifted Children: Recent Research. Learning And Individual Differences; 8:305-325.

15. Coutinho $S \mathrm{~A}$. The relationship between goals, metacognition, and academic success. Educate 2007; 7(1):39-47.

16. Narang D, Saini S. Metacognition and Academic performance of Rural Adolescents. Stud Home Com Sci 2013; 7(3):167-175.

17. Young A, Fry J D. Metacognitive awareness and academic achievements in college students. Journal of the Scholarship of Teaching and Learning 2008; 8(2):1-10.

\section{Source of Support: Nil. Conflict of Interest: None Declared.}

Copyright: (c) the author(s) and publisher. IJMRP is an official publication of Ibn Sina Academy of Medieval Medicine \& Sciences, registered in 2001 under Indian Trusts Act, 1882.

This is an open access article distributed under the terms of the Creative Commons Attribution Non-commercial License, which permits unrestricted non-commercial use, distribution, and reproduction in any medium, provided the original work is properly cited.

Cite this article as: Pallavi Panchu, Biju Bahuleyan, Seethalakshmi K, TomThomas. Metacognitive Knowledge: A Tool For Academic Success. Int J Med Res Prof. 2016; 2(5):131-34. 